\title{
Consumer Characteristics and Shopping for Fashion in the Omni-channel Retail Environment
}

\author{
Jay Sang RYU*
}

Received: September 10, 2019. Revised: September 18. Accepted: October 05. 2019.

\begin{abstract}
Purpose: Omni-channel retailing is a new retail phenomenon. Consumers in the omni-channel environment do not rely on one channel but integrate different channels from the same retailers freely during a particular shopping journey. The purpose of this study is to better understand omni-channel shoppers in the fashion retailing context. The present study uses consumer characteristics -- fashion innovativeness, technology innovativeness, and fashion purchase involvement -- as determinants predicting consumers' omni-channel shopping intentions for fashion products.

Research design, data, and methodology: Data were collected from 403 U.S. consumers, and the Structural Equation Modeling (SEM) was performed to test proposed hypotheses. The survey for this research consisted of three parts. The first part measured consumer traits in terms of their innovativeness and purchase involvement. The second part was designed to measure consumers' omni-channel shopping intentions, and the third part gathered consumer demographic information.

Results: The findings confirmed that fashion innovativeness, technology innovativeness, and fashion purchase involvement positively affected consumers' omni-channel shopping intentions.

Conclusions: Fashion retailers should integrate various customer touchpoints and offer mobile-enabled technologies to boost consumer traffic to both online and offline stores. They also need to create a shopping environment that is optimized for customer engagement in various shopping processes and allow them to explore different shopping channel options for best purchase decisions.
\end{abstract}

Keywords: Omni-channel shopping, Fashion Innovativeness, Technology Innovativeness, Purchase Involvement, Fashion Retailing.

JEL Classifications: D12, E20, L1, M31, M37.

\section{Introduction}

The development of mobile and digital technologies and their applications to the retail industry have propelled the emergence of omni-channel retailing, the latest stage of the retail evolution involving retailers' channel offering. Retailers perceive that customers choose to shop through one distribution channel such as offline, online, or mobile channel or shop through multiple channels but without any interactions between them. Such customers are considered single-channel or multi-channel shoppers.

\footnotetext{
1 Associate Professor, Department of Fashion Merchandising, Texas Christian University, TCU 298630, Fort Worth, TX 76129 USA. Email: jay.ryu@tcu.edu

() Copyright: Korean Distribution Science Association (KODISA)
This is an Open Access article distributed under the terms of the Creative Commons Attribution NonCommercial License (https://creativecommons.org/licenses/by-nc/4.0/) which permits unrestricted noncommercial use, distribution, and reproduction in any medium, provided the original work is properly cited.
}

In the omni-channel shopping environment, retailers have begun to recognize that consumers switch from one channel to other channels freely and integrate them during a particular shopping journey (Huré, Picot-Coupey, \& Ackermann, 2017; Juaneda-Ayensa, Mosquera, \& Murillo, 2016). In other words, omni-channel consumers do not rely on one channel but use several available channels spontaneously from product search to fulfilment and for all processes in between. Coinciding with this changing view on how consumers utilize retailers' channel offerings, researchers have identified some keywords to distinguish multi-channel and omni-channel retailing. A multi-channel retail system is built on the multiple channels operated in parallel and focuses on responding to customers' choices of one channel over others (Juaneda-Ayensa et al., 2016). The development of an omni-channel retail system relies on the synchronization of multiple channels (Verhoef, Kannan, \& Inman, 2015) and focuses on providing transparent and 
consistent product and service information across the supply chain to accommodate customers' needs for a seamless shopping experience (Ailawadi \& Farris, 2017; Saghiri, Wilding, Mena, \& Bourlakis, 2017).

A recent survey of 46,000 U.S. consumers revealed that about $73 \%$ are omni-channel consumers who generally shop more frequently and spend more money than nonomni-channel shoppers (Sopadjieva, Dholakia, \& Benjamin, 2017). Since a growing number of omni-channel consumers tend to be lucrative shoppers, understanding this segment has become an important undertaking for retailers. Researchers have attempted to advance the theoretical and practical understanding of consumers' channel preference and usage in various contexts (Ailawadi \& Farris, 2017; Cummins, Peltier, \& Dixon, 2016; Huré et al., 2017; Juaneda-Ayensa et al., 2016; Saghiri et al., 2017). However, they have rarely exposed omni-channel shoppers for fashion products. Since consumer behaviors and channel choices vary across product categories (Verhagen, Boter, \& Adelaar, 2010), and a successful business integration of offline and online channels is still a pending task for many fashion retailers (Guercini, Mir Bernal, \& Prentice, 2018), the purpose of this study is to better understand omni-channel shoppers in the fashion retailing context.

This study defines omni-channel shoppers as those who use multiple channels (physical stores, websites, and mobile apps) of the same retailer spontaneously during a single shopping journey. Previous studies have suggested that fashion innovativeness and purchase involvement are significant personal traits of fashion consumers (Cardoso, Costa, \& Novais, 2010; Cho \& Workman, 2011; Ryu, 2011), and technology innovativeness is an important predictor for consumers' online or mobile shopping intentions (Celik \& Kocaman, 2017; Lu, 2014). Thus, the present study uses these consumer characteristics -- fashion innovativeness, technology innovativeness, and fashion purchase involvement -- as determinants predicting consumers' omnichannel shopping intentions for fashion products.

\section{Literature Review}

\subsection{Fashion Innovativeness}

Researchers suggest a domain-specific innovativeness as an important precursor for consumers' purchase intentions of new products in the related product category (Tajeddini \& Nikdavoodi, 2014). Accordingly, fashion innovativeness refers to the level of an individual's innovative tendency that determines one's openness and willingness to accept new fashion products, trends, and styles (Jun \& Rhee, 2009). Fashion innovative consumers are innovative in the use of existing products and services (Choo, Sim, Lee, \& Kim,
2014). They are more creative and exploratory in nature when shopping for fashion and, thus may seek various shopping options available to them. Consumers in high fashion innovativeness tend to use different channels for their cloth shopping (Cho \& Workman, 2011) and search fashion products more extensively using various shopping channels (van Delft, 2013). For example, they tend to adopt a mobile version of fashion catalogs as well as a conventional print version for product information and buying options and utilize mobile-enabled tools to communicate with retailers for product and promotional information (Jai \& Tung, 2015). These behavioral propensities suggest that fashion innovative consumers are likely to utilize various shopping channels during a shopping journey for fashion products. Thus, the following hypothesis is proposed:

H1: Fashion innovativeness is positively associated with consumers' omni-channel shopping intentions.

\subsection{Technology Innovativeness}

Technology innovativeness is defined as an individual's tendency to adopt a new technology or technology-based system. In the retailing context, omni-channel shopping can be viewed as the latest technology-based system, as it involves mobile technology and the integration of different channel options to create seamless shopping environment from start to finish. A reasonable number of studies have investigated the influence of technology innovativeness on consumer adoption of new technology-based shopping options and confirmed that a positive and significant relationship exists between the two (Başgőze, 2015; Boyle \& Ruppel, 2006; Celik \& Kocaman, 2017; Mummalaneni, Meng, \& Elliott, 2016). Consumers with a higher level of technology innovativeness tend to use mobile-based sources for product search and product information (Jai \& Tung, 2015). They also display higher purchase intentions using omni-channel shopping options (Juaneda-Ayensa et al., 2016). Thus, the following hypothesis is proposed:

H2: Technology innovativeness is positively associated with consumers' omni-channel shopping intentions.

\subsection{Fashion Purchase Involvement}

Purchase involvement is the level of individuals' attention or apprehension toward the product choice or purchase decision they make (Hawkins, Best, \& Coney, 1986) and relates closely and positively to purchase intentions (Amornpashara, Rompho, \& Phadoongsitthi, 2015). Consumers with a high degree of purchase involvement tend to increase their search efforts for what to buy and how 
to buy (Beatty \& Smith, 1987). Consumers' purchase involvement varies by product types. The high purchase involvement products induce consumers to be more involved in their purchase decisions (Browne \& Kaldenberg, 1997). Thus, consumers make extra efforts to evaluate various product- and shopping-related information and actively try various channel options when shopping for such products (Johnson, Banks, Smith, \& Seo, 2017). They are also willing to use mobile devices more extensively during the various stages of the shopping process (Holmes, Bryne, Rowley, 2013). Since fashion is the product category that requires the high purchase involvement (O'Cass, 2004), consumers are likely to utilize various shopping channels and resources during a particular shopping journey for fashion products. Thus, the following hypothesis is proposed:

H3: Fashion purchase involvement is positively associated with consumers' omni-channel shopping intentions.

\section{Method}

\subsection{Measures}

The survey for this research consisted of three parts. The first part measured consumer traits in terms of their innovativeness and purchase involvement. A six-item fashion innovativeness scale (Goldsmith \& Hofacker, 1991) and a seven-item technology innovativeness scale (Parasuraman, 2000) were adopted to measure consumers' innovative tendencies toward fashion and technology, respectively. The fashion purchase involvement was evaluated with Mittal's (1989) four-item purchase decision involvement scale. Wording used in the survey was modified to reflect purchasing of fashion products. Seven-level Likert scales ( 1 - strongly disagree and 7 - strongly agree) were used to record consumers' responses. The second part was designed to measure consumers' omni-channel shopping intentions. A three-item behavior intention scale was adopted from the previous studies (Madahi \& Sukati, 2016; Ryu, 2011; Ryu \& Murdock, 2013). Survey wording was modified to reflect the omni-channel shopping environment, and seven-level Likert scales (1 - strongly disagree and 7 strongly agree) were employed. The third part gathered consumer demographic information, such as consumers' age, gender, income, and shopping experiences with mobile devices.

\subsection{Data Collection}

This study hired a consumer panel through an online research firm. Sampling criteria were male and female consumers of 18 years or older who reside in the United
States. Those qualified participants were first asked to answer a series of questions about their omni-channel shopping experiences. A total of 403 consumers were identified as omni-channel shoppers and completed online survey. Table 1 presents the description of the survey participants.

Table 1: Sample Description

$(n=403)$

\begin{tabular}{|lr|}
\hline \multicolumn{2}{|l|}{ Sample \% } \\
\hline Male & \\
\hline Female & 49.6 \\
\hline Age & 50.4 \\
\hline $18-24$ & 10.7 \\
\hline $25-34$ & 24.3 \\
\hline $35-44$ & 28.5 \\
\hline $45-54$ & 24.8 \\
\hline 55 or above & 11.7 \\
\hline Income & 13.9 \\
\hline Under $\$ 20,000$ & 19.9 \\
\hline$\$ 20,000-\$ 39,999$ & 20.6 \\
\hline$\$ 40,000-\$ 59,999$ & 16.1 \\
\hline$\$ 60,000-\$ 79,999$ & 11.4 \\
\hline$\$ 80,000-\$ 99,999$ & 10.9 \\
\hline$\$ 100,000-\$ 149,999$ & 7.1 \\
\hline$\$ 150,000$ or more &
\end{tabular}

\subsection{Data Analysis}

This research utilized various methods to evaluate the quality of measurement scales and proposed research model using IBM SPSS and Amos 23. First, the series of preliminary analyses were run on the collected data. The results of the histograms and scatter-plots confirmed the normal distribution of the measurement items and nonexistence of significant outlying values. A Varimax rotation factor analysis was performed to review whether measurement items loaded as distinct components, and four factors emerged as assumed. Two items of the technology innovativeness scale were excluded from the analysis because their factor loadings were less than a cut-off value of 0.6 (Matsunaga, 2010). Cronbach's alpha was used to assess the internal consistency of measurement items. The value ranged from 0.87 to 0.94 , suggesting internal reliability of the scales.

Second, the Confirmatory Factor Analysis (CFA) was employed to test the reliability and validity of the measurement model, and the Structural Equation Modeling (SEM) was performed to evaluate the research model depicting the hypothesized relationships among constructs (Anderson \& Gerbing, 1988). The overall model fit for the 
measurement model and research model was estimated with Chi-square $\left(x^{2}\right)$, Root Mean Square Error of Approximation (RMSEA), Goodness of Fit Index (GFI), Comparative Fit Index (CFI), Normed Fit Index (NFI), and Standardized Root Mean Square Residual (SRMR) (Kline, 2005).

\section{Results}

\subsection{Measurement Model}

The confirmatory factor analysis was performed to assess the reliability and validity of the measurement model. The fit statistics of the confirmatory factor analysis confirmed that the measurement model met the suggested cutoff values and factor loadings ranged from 0.74 to 0.88 with $p$-values < 0.001. (Hu \& Bentler, 1999; Steiger, 2007). It also confirmed an excellent model fit: $X^{2}=243.3$ with $124 d f$ at $p$-value < 0.001 ; RMSEA of 0.049 ; GFI of 0.94 ; CFI of 0.98 ; $\mathrm{NFI}$ of 0.95 ; and SRMR of 0.053 . The composite reliability (CR) ranged from 0.87 to 0.92 , and the average variance extracted (AVE) ranged from 0.64 to 0.70 . Table 2 and 3 present the measurement model results and descriptive statistics, respectively.

Table 2: Measurement model results

\begin{tabular}{|c|c|}
\hline Constructs and Items & Factor Loading ${ }^{a}$ \\
\hline \multicolumn{2}{|l|}{ Fashion Innovativeness (Cronbach's $\alpha=0.94 ; C R^{\mathrm{b}}=0.92 ; A V E^{\mathrm{c}}=0.66$ ) } \\
\hline First among friends to know the latest fashion trends & 0.83 \\
\hline Do little shopping for new fashion compared to my friends ${ }^{*}$ & 0.80 \\
\hline First among friends to purchase a new outfit or fashion & 0.87 \\
\hline More knowledgeable in fashion than other people & 0.88 \\
\hline Buy a new outfit if I know it is available & 0.77 \\
\hline Consider buying a new fashion brand or style even if it is not yet popular & 0.74 \\
\hline
\end{tabular}

Technology Innovativeness (Cronbach's $\alpha=0.89 ; C R^{b}=0.90 ; A V E^{c}=0.64$ )

My friends know more about new technologies than me*

Can figure out new high-tech products and services without others' help

0.83

$\begin{array}{ll}\text { Keep up with the latest technological development in my areas of interest } & 0.75\end{array}$

$\begin{array}{ll}\text { Enjoy the challenge of figuring out high-tech gadgets } & 0.78\end{array}$

Have a fewer problems than other people in making technology work for me 0.83

Fashion Purchase Involvement (Cronbach's $\alpha=0.87 ; C R^{b}=0.88 ; A V E^{c}=0.64$ )

Care a great deal as to which fashion products I buy

Fashion products available in the market are all very alike

Omni-channel Shopping Intentions (Cronbach's $\alpha=0.87 ; C R^{b}=0.87 ; A V E^{c}=0.70$ )

Would use various shopping channels the retailer offers on a particular

shopping situation for fashion

Would purchase a product from the retailer's website using my mobile phone

if cannot find a correct size of color at the store

Would search product information using my mobile phone while

${ }^{a}$ All significant at .001; ${ }^{b}$ Composite reliability; ${ }^{c}$ Average variance extracted; " reverse coding

Model fit: $\mathrm{X}^{2}=243.3(d f=124), p$-value $<.001 ; \mathrm{RMSEA}=.049 ; \mathrm{GFI}=0.94 ; \mathrm{CFI}=.98 ; \mathrm{NFI}=.95 ; \mathrm{SRMR}=.053$ 
Table 3: Correlation matrix and descriptive statistics

\begin{tabular}{|c|c|c|c|c|c|c|}
\hline & $\mathrm{FI}$ & $\mathrm{TI}$ & FDI & OSI & $M^{a}$ & $S D^{b}$ \\
\hline Fashion Innovativeness (FI) & 1 & & & & 3.60 & 1.52 \\
\hline Technology Innovativeness ( $\mathrm{TI}$ ) & .37 & 1 & & & 4.80 & 1.22 \\
\hline Fashion Purchase Involvement (FDI) & .48 & .21 & 1 & & 4.73 & 1.26 \\
\hline Omni-channel Shopping Intention (OSI) & .45 & .35 & .38 & 1 & 4.88 & 1.35 \\
\hline
\end{tabular}

All correlations significant at the 0.01 level

${ }^{\mathrm{a}}$ Mean; ${ }^{\mathrm{b}}$ Standard deviation

\subsection{Structural Model and Hypotheses Testing}

The Structural Equation Modeling (SEM) was used to assess the proposed research model and hypotheses. The overall fit indices indicated a good model fit: $X^{2}=271.3$ with $d f=126$ at $p$-value $<0.001$; RMSEA of 0.054 ; GFI of 0.93 ; $\mathrm{CFI}$ of 0.97 ; NFI of 0.95 ; and SRMR of 0.054 . Figure 1 shows the path coefficients and the results of statistical significance.

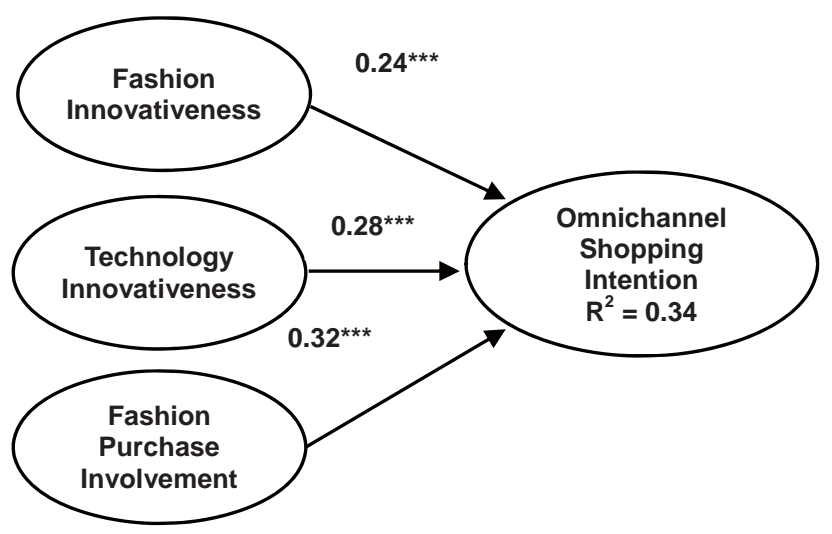

${ }^{* * *}$ Significant at 0.001 level

Model fit: $\mathrm{X}^{2}=271.3(d f=126), p$-value <.001; RMSEA = .054; $\mathrm{GFI}=0.93 ; \mathrm{CFI}=.97 ; \mathrm{NFI}=.95 ; \mathrm{SRMR}=.054$

Figure 1: Path Coefficient Results

The fashion innovativeness positively affected consumers' omni-channel shopping intentions when purchasing fashion products, supporting Hypothesis $1(\beta=0.24, t$-value $=3.55$, $p<0.001)$. This result implies that consumers who are keen to the latest fashion trends, like to buy new clothing, and adopt new styles and brands with little effort are likely to utilize omni-channel shopping options. This finding coincides with the literature on innovativeness, which suggests that innovative consumers are more likely to engage in shopping processes actively and innovatively through various channels and methods (Choo et al., 2014; van Delft, 2013).

The positive effect of the technology innovativeness on consumers' omni-channel shopping intentions was identified. Thus, Hypothesis 2 is supported $(\beta=0.28, t$-value $=4.07, p$ $<0.001)$. This finding aligns with the previous research confirming that technology innovativeness leads to consumers' active involvement in using a new technologyenabled system (Başgőze, 2015; Boyle \& Ruppel, 2006; Celik \& Kocaman, 2017; Jai \& Tung, 2015; Mummalaneni et al., 2016). It suggests that consumers who are believed to be knowledgeable about the latest technologies and interested in learning about new technological developments and trends tend to use omni-channel shopping options. Also, this discovery is consistent with the previous research, which showed a positive relationship between innovativeness and consumers' intentions to adopt the technology-based products and services (Ling \& Yuan, 2012).

Consumers' purchase involvement for fashion products is positively related to their omni-channel shopping intentions, supporting Hypothesis $3(\beta=0.32, t$-value $=4.16, p<0.001)$. This relationship can be interpreted that consumers are inclined to pursue omni-channel shopping experiences when they are making purchase decisions for the highly involved products such as fashion. It also supports previous studies which confirm that fashion is one of product categories that requires consumers' high purchase involvement (O'Cass, 2004) and that consumers for such products seek various shopping options (Browne \& Kaldenberg, 1997; Holmes et al., 2013; Johnson et al., 2017). 


\section{Conclusions}

To respond to a fast-changing and more-demanding retail environment and consumers' need for utilizing various touchpoints simultaneously during a shopping journey, retailers are reshaping their business strategies to offer their customers the omni-channel shopping experience. Due to the increased number of omni-channel shoppers and the need for understanding who they are (Sopadjieva et al., 2017), this study attempted to identify their personal traits in the context of shopping for fashion products.

The findings of this study confirmed that when consumers display a higher level of fashion innovativeness, their omnichannel shopping intentions become stronger. The previous studies have pointed out that making products available in all channels and allowing consumers to find product availability and make purchases in any of these channels are some key features of omni-channel retailing (Ailawadi \& Farris, 2017; Saghiri et al., 2017). Fashion innovative consumers enjoy new fashion products (Jun \& Rhee, 2009) and explore more inventive ways for purchasing them (Choo et al., 2014). The omni-channel shopping option allows them to be more flexible and more active in pre- and postshopping processes, such as search/compare, purchase, and fulfillment/return. Fashion innovative consumers can purchase items by using their mobile devices without delay and without traveling to other locations when a certain size or color is not available at the store they have initially visited. This flexibility of shopping transactions can be a strong motivation for fashion innovative consumers shopping at omni-channel retailers. To this end, fashion retailers should offer transparent and consistent merchandise and services across channels and integrate various customer touchpoints so that they do not lose sales when consumers want to maximize their shopping channel options. Since innovative consumers are often the first ones who introduce and promote new products and services to a large audience (Kim, Di Benedetto, \& Hunt, 2017), fashion retailers should also utilize this consumer group to promote and disseminate their omni-channel retail strategies to the customers.

This study also confirmed that when consumers display a higher level of technology innovativeness, their omnichannel shopping intentions become stronger. This finding is congruent with the previous studies that have established a positive link between technology innovativeness and the adoption of retail technologies (Başgőze, 2015; Celik \& Kocaman, 2017; Jai \& Tung, 2015; Mummalaneni et al., 2016). As the mobile technology is already an integral part of today's retail world and omni-channel shoppers prefer to use their own mobile devices for and during shopping (Yurova, Rippé, Weisfeld-Spolter, Sussan, \& Arndt, 2017), retailers should continue to best utilize customers' mobile touchpoint to create an omni-channel retail environment. They could boost foot traffic to their physical stores and web traffic to their e-commerce sites by offering various mobileoptimized marketing communications and promotions.

Lastly, this study confirmed that when consumers display a higher level of fashion purchase involvement, their omnichannel shopping intentions become stronger. This finding is in line with the previous studies which found that omnichannel shoppers prefer to take charge of their own shopping processes (Yurova et al., 2017) and make purchase decisions without help from the sales associates (Rippé, Weisfeld-Spolter, Yuroova, \& Sussan, 2015). Since fashion customers are highly involved in their fashion purchases, retailers need to create a shopping environment that is optimized for customer engagement in various shopping processes and allow them to explore different shopping options for best purchase decisions.

This study contributes to the current literature on omnichannel retailing by providing the elementary information about the relationship between consumers' personal characteristics, such as innovativeness and purchase involvement, and their omni-channel shopping intentions for fashion products. However, there are some limitations. Consumers who did not own a smart mobile device were excluded from participating in the survey. Although using a mobile channel during a shopping journey is a critical part of omni-channel retailing in general, it is not a requirement. This study acknowledges that some consumers may be omni-channel shoppers without using the mobile channel. Also, consumers were asked to express their omni-channel shopping intentions as if they were shopping for fashion products. Their intentions may vary depending on the product types. Thus, these limitations should be noted when interpreting the study outcomes.

Future research could include additional personal traits to examine their influences on omni-channel shopping behaviors and profile this consumer segment (Lazaris \& Vrechopoulos, 2014). Consumers' shopping values and motivations in various shopping contexts (e.g., utilitarian products vs. hedonic products) and omni-channel store environment could also be valuable contributions to the current literature (Lazaris \& Vrechopoulos, 2014). Since social media have become a crucial tool for retailers, the inclusion of social media as a series of omni-channel touchpoints would be an interesting area to explore as well. The Theory of Reasoned Action (Fishbein \& Ajzen, 1975) is well-documented as a theoretical foundation for consumer adoption of new technologies (Otieno, Liyala, \& Abeka, 2016) and shopping channel selections (Madahi \& Sukati, 2016). Thus, future research could adopt the TRA to scrutinize the effects of subjective norm, consumer attitudes, and intentions of becoming omni-channel shoppers. 


\section{References}

Ailawadi, K.L., \& Farris, P.W. (2017). Managing multi- and omni-channel distribution:

Metrics and research directions. Journal of Retailing, 93(1), 120-135.

Amornpashara, N., Rompho, N., \& Phadoongsitthi, M. (2015). A study of the relationship

between using Instagram and purchase intention. Journal of Global Business Advancement, 8(3), 354-370.

Anderson, J., \& Gerbing, D. (1988). Structural equation modeling in practice: A review and recommended twostep approach. Psychological Bulletin, 103(3), 411-423.

Başgőze, P. (2015). Integration of technology readiness (TR) into the technology

acceptance model (TAM) for m-shopping. International Journal of Scientific Research and Innovative Technology, 2(3). 26-35.

Beatty, S.E., \& Smith, S.M. (1987). External search effort: An investigation across several product categories. Journal of Consumer Research, 14, 83-95.

Boyle, R. \& Ruppel, C.P. (2006). The effects of personal innovativeness, perceived risk, and computer self-efficacy on online purchasing intent. Journal of International Technology and Information Management, 15(2), 61-73.

Browne, B.A., \& Kaldenberg, D.O. (1997). Conceptualizing self-monitoring: Links to materialism and product involvement. Journal of Consumer Marketing, 14(1), 3144.

Celik, H., \& Kocaman, R (2017). Roles of self-monitoring, fashion involvement and technology readiness in an individual's propensity to use mobile shopping. Journal of Systems and Information Technology, 19(3/4), 166-182.

Cardoso, C.R., Costa, H.S., \& Novais, L.A. (2010). Fashion consumer profiles in the Portuguese market: Involvement, innovativeness, self-expression and impulsiveness as segmentation. International Journal of Consumers Studies, 34, 638-647.

Cho, S., \& Workman, J. (2011). Gender, fashion innovativeness and opinion leadership, and need for touch: Effects on multi-channel choice and touch/nontouch preference in clothing shopping. Journal of Fashion Marketing and Management, 15(3), 363-382.

Choo, H.J., Sim, S.Y., Lee, H.K., \& Kim, H.B. (2014). The effect of consumers' involvement and innovativeness on the utilization of fashion wardrobe. International Journal of Consumer Studies, 38, 175-182.

Cummins, A., Peltier, J.W., \& Dixon, A. (2016). Omnichannel research framework in the context of personal selling and sales management: A review and research extensions. Journal of Research in Interactive Marketing, 10(1), 2016, 2-16.
Fishbein, M, \& Ajzen, I. (1975). Belief, Attitude, Intentions and Behavior: An Introduction to Theory and Research. Reading, MA: Addision-Wesley.

Goldsmith, R.E., \& Hofacker, C. F. (1991). Measuring consumer innovativeness. Journal of the Academy of Marketing Science, 19(3), 209-221.

Gurecini, S., Mir Bernal, P., \& Prentice, C. (2018). New marketing in fashion e-commerce. Journal of Global Fashion Marketing, 9(1), 1-8.

Hawkins, D.I, Best, R.J., \& Coney, K.A. (1986). Consumer behavior: Implications for marketing strategy. Plano, TX: Business Publications.

Holmes, A., Bryne, A., \& Rowley, J. (2013). Mobile shopping behavior: Insights into attitudes, shopping process involvement and location. International Journal of Retail \& Distribution Management, 42(1), 25-39.

Hu, L., \& Bentler, P.M. (1999). Cutoff criteria for fit indexes in covariance structure analysis: Conventional criteria versus new alternatives. Structural Equation Modeling, 6(1), 1-55.

Huré, E., Picot-Coupey, K., \& Ackermann, C.-L. (2017). Understanding omni-channel shopping value: A mixedmethod study. Journal of Retailing and Consumer Services, 39, 314-330.

Jai, T.-M., \& Tung, T. (2015). Fashion innovativeness, information technology innovativeness, and prior experience as factors influencing adoption of apparel mobile e-catalogs. Journal of Global Fashion Marketing, 6(3), 163-179.

Johnson, C., Banks, L., Smith, D., \& Seo, J.-I. (2017). The effect of product involvement onstore preference and clothing benefits sought for African-American female students. Journal of Applied Business Research, 33(1), 107-114.

Juaneda-Ayensa, E., Mosquera, A., \& Sierra Murillo, Y. (2016). Omni-channel customer behavior: Key drivers of technology acceptance and use and their effects on purchase intention. Frontiers in Psychology, 7, 1-11.

Jun, D.G., \& Rhee, E.Y. (2009). The effects of fashion innovativeness and style-innovation attributes on fashion adoption. Journal of the Korean Society of Clothing and Textiles, 33, 1564-1574.

Kim, W., Di Benedetto, C.A., \& Hunt, J.M. (2017). Consumer innovativeness and international consumer behavior: Comments and extensions. Journal of Global Scholars of Marketing Science, 27(3), 184-194.

Kline, R.B. (2005). Principles and practice of structural equation modeling ( $2^{\text {nd }}$ ed.). New York, NY: Guilford Press.

Lazaris, C., \& Vrechopoulos, A. (2014). From multichannel to "omnichannel" retailing: Review of the literature and calls for research. Paper presented at the $2^{\text {nd }}$ International 
Conference on Contemporary Marketing Issues (ICCMI), Athens, Greece.

Ling, M.X., \& Yuan, P. (2012). An empirical research: Consumer intention to use smartphone based on consumer innovativeness. Paper presented at the $2^{\text {nd }}$ International Conference on Consumer Electronics, Communications and Networks (CECNet) (pp.2368-2371).

Lu, J. (2014). Are personal innovativeness and social influence critical to continue with mobile commerce? Internet Research, 24(2), 134-159.

Madahi, A., \& Sukati, I. (2016). Determinants of the channel selection and choice intention: A marketing perspective. Journal of Global Business Advancement, 9(4), 357-389.

Matsunaga, M. (2010). How to factor-analyze your data right: Do s, don'ts, and how-to s. International Journal of Psychological Research, 3(1), 97-110.

Mittal, B. (1989). Measuring purchase-decision involvement. Psychology \& Marketing, 6(2), 147-162.

Mummalaneni, V., Meng, J., \& Elliott, K.M. (2016). Consumer technology readiness and e-service quality in e-tailing: What is the impact on predicting online purchasing? Journal of Internet Commerce, 15(4), 311331.

O'Cass, A. (2004). Fashion clothing consumption: Antecedents and consequences of fashion clothing involvement. European Journal of Marketing, 38(7), 869882.

Otieno, O.C., Liyala, S., Odongo, B.C., \& Abeka, S. (2016). Theory of reasoned action as an underpinning to technological innovation adoption studies. World Journal of Computer Application and Technology, 4(1), 1-7.

Parasuraman, A. (2000). Technology readiness index (TRI): A multiple-item scale to measure readiness to embrace new technologies. Journal of Service Research, 2(4), 307320.

Rippé, C.B, Weisfeld-Spolter, S., Yorova, Y., \& Sussan, F. (2015). Is there a global multichannel consumer? International Marketing Review, 32, 329-349.
Ryu, J.S. (2011). Consumer attitudes and shopping intentions toward pop-up fashion stores. Journal of Global Fashion Marketing, 2(3), 139-147.

Ryu, J.S., \& Murdock, K. (2013). Consumer acceptance of mobile marketing communications using the QR code. Journal of Direct, Data and Digital Marketing Practice, 15(2), 111-124.

Saghiri, S., Wilding, R. Mena, C., \& Bourlakis, M. (2017). Toward a three-dimensional framework for omni-channel. Journal of Business Research, 77, 53-67.

Sopadjieva, E., Dholakia, U.M., \& Benjamin, B. (2017). A study of 46,000 shoppers shows that omni-channel retailing works. Harvard Business Review. Retrieved on April 22, 2018, from https://hbr.org/2017/01/a-study-of46000-shoppers-shows-that-omni-channel-retailing-works.

Steiger, J.H. (2007). Understanding the limitations of global fit assessment in structural equation modeling. Personality and Individual Differences, 42(5), 893-898.

Tajeddini, K., \& Nikdavoodi, J.N. (2014). Cosmetic buying behaviour: Examining the effective factors. Journal of Global Scholars of Marketing Science, 24(4), 395-410.

van Delft, W.C.J.M. (2013). Omni channel shopping behavior during the customer journey. Eindhoven, Netherlands: Eindhoven University of Technology.

Verhagen, T., Boter, J., \& Adelaar, T. (2010). The effect of product type on consumer preferences for website content elements: An empirical study. Journal of Computer-Mediated Communication, 16, 139-170.

Verhoef, P.C., Kannan, P.K., \& Inman, J.J. (2015). From multi-channel retailing to omni-channel retailing: Introduction to the special issue on multi-channel retailing. Journal of Retailing, 91(2), 174-181.

Yurova, Y., Rippé, C.B., Weisfeld-Spolter, S., Sussan, F., \& Arndt, A. (2017). Not all adaptive selling to omniconsumers is influential: The moderating effect of product type. Journal of Retailing and Consumer Service, 34, 271277. 